\title{
PENYULUHAN KESADARAN AIR BERSIH DAN HIDUP SEHAT DESA KEDUNG DALEM - KECAMATAN MAUK BANTEN
}

\author{
Candra Yulius Tahya ${ }^{1}$, Kelly Sinaga ${ }^{1}$, Debora Sitinjak ${ }^{1}$, Friska Purba1 \\ ${ }^{1}$ Program Studi Pendidikan Kimia, Universitas Pelita Harapan - Tangerang Banten \\ candra.tahya@uph.edu
}

\begin{abstract}
Abstrak
Lingkungan sangat berpengaruh terhadap keberlangsungan hidup manusia sehingga perlu dijaga dan dilestarikan. Pada kenyataannya di Desa Kedung Dalem, berdasarkan hasil wawancara dengan LSM mitra, menunjukkan bahwa sebagian besar masyarakatnya belum mempunyai kesadaran yang tinggi untuk menerapkan gaya hidup sehat dan menjaga kebersihan lingkungannya. Salah satu upaya untuk mengatasi permasalahan tersebut, Program Studi Pendidikan Kimia UPH melakukan kegiatan PkM melalui penyuluhan pentingnya gaya hidup sehat dan kebersihan lingkungan pada 9 Mei 2018. Mendahului kegiatan peyuluhan, Tim PkM melakukan observasi dan pengambilan sampel dari sumber air masyarakat di Desa Kedung Dalem. Sampel air tersebut dibawa ke laboratoium untuk dilakukan analisis kadar logam berat berbahaya. Kegiatan ini bertujuan untuk memberikan informasi kepada masyarakat sumber-sumber air yang baik dan rendah kadar logam berat berbahaya, dan menyadarkan masyarakat akan pentingnya kesehatan dan kebersihan lingkungan di kedua desa tersebut. Tim penyuluh juga merancang suatu alat penyaring air sederhana, sebagai contoh untuk masyarakat di Desa Kedung Dalam sehingga dapat dibuat untuk mengatasi kendala sumber air yang kotor dan tercemar. Hasil analisis AAS menunjukkan bahwa kandungan logam berat berbahaya yakni Timbal $(\mathrm{Pb})$, Kromium $(\mathrm{Cr})$ dan Kadmium $(\mathrm{Cd})$, ternyata masih pada rentang konsentrasi maksimum yang diperbolehkan oleh Peraturan Menteri Kesehatan Republik Indonesia No. 492/MENKES/PER/IV/2010. Contohnya konsentrasi logam $\mathrm{Pb}$ dalam sampel air adalah < 0,04 mg/L masih pada rentan kadar maksimum yang diperbolehkan yaitu $0,01 \mathrm{mg} / \mathrm{L}$. Melalui penyuluhan ini, masyarakat dapat mengaplikasikan cara menjaga kesehatan dan kebersihan lingkungan serta mengetahui dampaknya bagi kesehatan, juga mengembangkan kesadaran diri akan pentingnya kebersihan lingkungan sehingga dapat meningkatkan taraf kesehatan masyarakat Desa Kedung Dalem serta memperindah lingkungan masyarakat.
\end{abstract}

Kata Kunci: Kebersihan lingkungan, Kedung Dalem, kesehatan masyarakat, kualitas air.

PENDAHULUAN

Desa Kedung Dalem, Kecamatan Mauk, Provinsi Banten mengalami berbagai persoalan kebersihan lingkungan yang disebabkan oleh kurangnya pemahaman masyarakat akan pentingnya kebersihan dan sanitasi lingkungan. Oleh karena pengelolaan kebersihan yang tidak menjadi prioritas dalam kehidupan masyarakat tersebut dan rendahnya tingkat Pendidikan masyarakat di Desa Kedung Dalem juga menjadi salah satu penyebab rendahnya kesadaran masyarakat akan kebersihan dan kesehatan (Profil DinKes Tangerang, 2010) maka sering timbul penyakit diantaranya DBD dan tifus yang disebabkan adanya kesempatan nyamuk Aedis Aegypti untuk berkembang biak dan kurangnya kebersihan lingkungan. Perkembangbiakan nyamuk banyak terdapat pada sawah, rawa, danau, empang, comberan, dan saluran irigasi untuk mengairi sawah serta tempurung dan pelepah kelapa yang dibiarkan berserakan (Dharma et al., 2004).

Lingkungan Hidup dan Kebencanaan 
Untuk mengatasi persoalan yang ada di Desa Sasak dan Kedung Dalem, maka dilakukan kegiatan penyuluhan tentang pentingnya kesehatan maupun sanitasi yang hygiene, agar masyarakat mengetahui dampak kedua hal tersebut bagi kehidupan masyarakat. Dengan sumber daya yang dipunyai oleh Teachers College, maka dilakukan kegiatan penyuluhan maupun tutorial tentang pentingnya gaya hidup sehat dan pentingnya kebersihan lingkungan serta pengelolaan sampah oleh dosen dan mahasiswa.

\section{METODE}

Pelaksanaan observasi dan mengambilan sampel air dari Desa Kedung Dalem.

\section{Observasi}

Anggota Tim PkM yang telah ditunjuk akan melakukan observasi ke Desa Kedung Dalem dengan didampingi oleh mitra Habitat for Humanity. Tim menggunakan metode wawancara dan kuisioner untuk mengetahui tingkat kesadaran masyarakat terhadap bahaya logam berat dan lingkungan yang tidak bersih dan jenis penyakit yang sering diderita oleh masyarakat. Dipilih secara acak, 5 orang anggota masyarakat diwawancara. Juga dilakukan observasi kondisi lingkungan di Desa, seperti tempat sampah, tempat MCK, dan sumber air minum.

2. Pengambilan sampel air dari beberapa sumber

Sampel air diambil oleh Tim dari beberapa sumber, seperti sumber air minum dan MCK masyarakat. Setiap sampel sebanyak $1 \mathrm{~L}$ air diambil dari 2 lokasi di Desa Kedung Dalem. Sampel selanjutnya dibawa ke laboratorium. Sampel dilakukan perlakuan awal seperti penyaringan, pengukuran $\mathrm{pH}$. Selanjutnya setiap $100 \mathrm{~mL}$ sampel dianalisis kadar logam berat yaitu Timbal $(\mathrm{Pb})$, Kadmium (Cd), Merkuri (Hg) dan Krom (Cr) dengan alat AAS. Logam-logam ini adalah logam berbahaya bagi kesehatan masyarakat dan dapat menyebabkan berbagai penyakit berbahaya jika konsentrasinya melebihi ambang batas (BPOM, 2010).

3. Pembuatan alat penyaringan air sederhana

Untuk membantu masyarakat Desa Kedung Dalam yang mengalami masalah air kotor dan keruh dari sumber sumur maka Tim PkM Program Studi
Pendidikan Kimia melakukan perakitan alat penyaringan sederhana yang dibuat di Laboratoium Teachers College dan di Gedung Dormitory TC. Semua bahan yang dibutuhkan dibeli dari beberapa toko bahan bangunan dan perpipaan, selanjutnya dirangkai sesuai rancangan yang telah ditetapkan (Gambar 1).

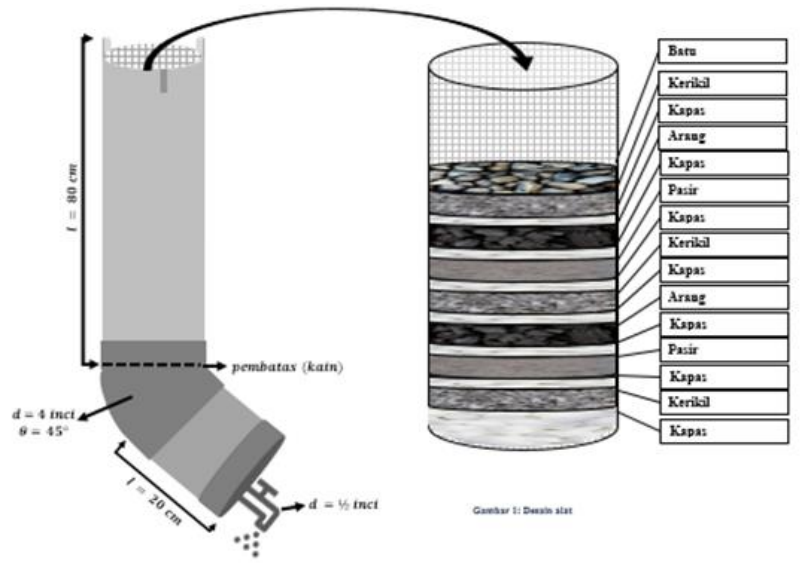

Gambar 1. Rancangan dan komponen alat penyaringan air sederhana

4. Pelaksanaan Penyuluhan terhadapat masyarakat Desa Sasak dan Kedung Dalem.

a. Penyajian data informasi yang telah dikumpulkan.

b. Penyuluhan mengenai kebersihan lingkungan dan sanitasi sehingga dapat memperbaiki kesehatan masyarakat.

c. Praktek teknik mengolahan sampah yang baik.

d. Aktifitas diskusi dan tanya jawab.

\section{HASIL DAN PEMBAHASAN}

\section{Pelaksanaan Kegiatan}

Kegiatan penyuluhan kesadaran air bersih dan hidup sehat dilaksanakan pada hari Rabu, 9 Mei 2018. Bentuk kegiatan adalah ceramah tentang kesadaran air bersih warga yang perlu ditingkatkan dan pola hidup sehat warga yang perlu diperbaiki. Disiapkan juga suatu alat penyaringan air sederhana yang dapat digunakan oleh warga dalam menyaring air yang kotor dan berwarna yang dialami oleh warga masyarakat desa Kedung Dalem, Kecamatan Mauk, 
Kabupaten Tangerang Banten. Diperkenalkan kepada warga desa Kedung Dalem bagaimana cara membuat dan menggunakan alat penyaringan air sederhanya tersebut.

Kegiatan penyuluhan berlangsung di Sekolah Dasar Negeri Kedung Dalem pada Jam 13.00 WIB sampai 15.10 WIB. Adapun kegiatan penyuluhan ini memiliki rangkaian waktu sebagaimana ditunjukkan oleh Tabel 1.

Tabel 1. Rangkaian Acara Penyuluhan Kesadaran Air bersih dan Hidup Sehat

\begin{tabular}{|l|l|l|}
\hline No & Waktu & Kegiatan \\
\hline 1 & $\begin{array}{l}13.00-13.05 \\
\text { WIB }\end{array}$ & $\begin{array}{l}\text { Pembukaan Kegiatan dan } \\
\text { Doa sesuai kepercayaan masing- } \\
\text { masing }\end{array}$ \\
\hline 2 & $\begin{array}{l}13.05-13.15 \\
\text { WIB }\end{array}$ & $\begin{array}{l}\text { Pembagian buku Notes dan Pena } \\
\text { kepada warga }\end{array}$ \\
\hline 3 & $\begin{array}{l}13.15-13.30 \\
\text { WIB }\end{array}$ & Kegitan Pre-test bagi warga \\
\hline 4 & $\begin{array}{l}13.30-14.30 \\
\text { WIB }\end{array}$ & $\begin{array}{l}\text { Pembawaan Materi Penyuluhan } \\
\text { oleh Dosen: Pak Candra, Ibu } \\
\text { Debora dan } \\
\text { Ibu Friska }\end{array}$ \\
\hline 5 & $\begin{array}{l}\text { W.30 - 14.45 } \\
\text { WIB }\end{array}$ & $\begin{array}{l}\text { Peragaan alat penyaringan } \\
\text { sederhana oleh Pak Candra }\end{array}$ \\
\hline 6 & $\begin{array}{l}14.45-15.00 \\
\text { WIB }\end{array}$ & \begin{tabular}{l} 
Post-Test bagi warga \\
\hline 7
\end{tabular} \\
\begin{tabular}{l} 
WIB -15.00 \\
\hline
\end{tabular} & $\begin{array}{l}\text { Penutupan dan pembagian souvenir } \\
\text { kepada warga }\end{array}$ \\
\hline
\end{tabular}

\section{Hasil Analisis Sampel Air dari Desa Kedung Dalem}

Sebelum dilaksanakannya kegiatan penyuluhan, ketua kegiatan PkM melakukan survey tempat bersama dengan mitra LSM Habitat for Humanity dan melakukan pengambilan sampel air dari sumber air yang digunakan sehari-hari oleh warga masyarakat di Desa Kedung Dalem untuk analisis. Sampel yang diambil dari dua lokasi yaitu di tempat penampungan air dan MCK RT 1 (lokasi GPS: $\left.6^{\circ} 04^{\prime} 50.8^{\prime \prime} \mathrm{S} 106^{\circ} 31^{\prime} 12.2^{\prime \prime} \mathrm{E}\right)$ dan MCK RT 2 (lokasi GPS: $\left.6^{\circ} 04^{\prime} 46.4^{\prime \prime S} 1^{\prime} 06^{\circ} 31^{\prime} 27.1^{\prime \prime E}\right)$, Desa Kedung Dalem.

Sampel kemudian disiapkan di laboratorium kimia sebelum dikirimkan ke Laboratorium Pengujian, Pusat Teknologi Lingkungan, Badan Pengkajian dan Penerapan Teknologi, Serpong Tangerang untuk analisis AAS (Atomic Absorption Spectrophotometry) terhadap kandungan 3 logam berat yaitu Timbal $(\mathrm{Pb})$, Kromium $(\mathrm{Cr})$ dan
Kadmium (Cd). Hasil analisis AAS ini dapat dilihat pada Tabel 2.

Logam berat berbahaya hakikatnya ada disekitar kita terkandung dalam berbagai produk industri seperti cat dan baterai/aki tetapi sedikit orang yang menyadari jika logam berat dapat mudah masuk ke dalam tubuh dan memicu kelainan dan keluhan penyakit berbahaya di dalam berbagai jaringan tubuh manusia (Susanti, Mustikaningtyas, \& Sasi, 2014).

Hasil analisis AAS menunjukkan bahwa kandungan logam berat berbahaya yakni Timbal $(\mathrm{Pb})$, Kromium $(\mathrm{Cr})$ dan Kadmium $(\mathrm{Cd})$, ternyata masih pada rentang konsentrasi maksimum yang diperbolehkan oleh Peraturan Menteri Kesehatan Republik Indonesia (MENKES RI, 2010).

Tabel 2. Data Konsentrasi Logam Berat dalam Sampel Air Kedung Dalem

\begin{tabular}{|l|l|l|}
\hline Kode Sampel & $\begin{array}{l}\text { Konsentrasi } \\
\text { Logam yang } \\
\text { Dianalisis Dalam } \\
\text { Sampel Air }\end{array}$ & $\begin{array}{l}\text { Konsentrasi } \\
\text { maksimum yang } \\
\text { Diperbolehkan } \\
\text { DEPKES }\end{array}$ \\
\hline \multirow{5}{*}{ KD1A } & $\begin{array}{l}\text { Timbal }(<0,04 \\
\mathrm{mg} / \mathrm{L})\end{array}$ & $0,01 \mathrm{mg} / \mathrm{L}$ \\
\cline { 2 - 3 } & $\begin{array}{l}\text { Kromium }(<0,06 \\
\mathrm{mg} / \mathrm{L})\end{array}$ & $0,05 \mathrm{mg} / \mathrm{L}$ \\
\cline { 2 - 3 } & $\begin{array}{l}\text { Kadmium }(<0,006 \\
\mathrm{mg} / \mathrm{L})\end{array}$ & $0,003 \mathrm{mg} / \mathrm{L}$ \\
\hline \multirow{5}{*}{ KD2B } & $\begin{array}{l}\text { Timbal }(<0,04 \\
\mathrm{mg} / \mathrm{L})\end{array}$ & $0,01 \mathrm{mg} / \mathrm{L}$ \\
\cline { 2 - 3 } & $\begin{array}{l}\text { Kromium }(<0,06 \\
\mathrm{mg} / \mathrm{L})\end{array}$ & $0,05 \mathrm{mg} / \mathrm{L}$ \\
\cline { 2 - 3 } & $\begin{array}{l}\text { Kadmium }(<0,006 \\
\mathrm{mg} / \mathrm{L})\end{array}$ & $0,003 \mathrm{mg} / \mathrm{L}$ \\
\hline
\end{tabular}

Hasil ini menunjukkan sumber air di lokasi di kedua RT di Desa Kedung Dalem yang dianalisis memiliki konsentrasi logam berat Timbal, Kromium dan Kadmium masih rendah dan berada pada rentang konsentrasi yang diperbolehkan oleh Departemen Kesehatan Republik Indonesia. Kedua lokasi sumber air ini kemudian direkomendasikan kepada masyarakat untuk hanya menggunakan untuk air cuci dan mandi dan bukan untuk air minum.

\section{Pembuatan Alat Penyaringan Air Sederhana}

Alat penyaringan air sederhana yang dapat dilihat pada (Gambar 2a). Alat ini dibuat dengan 
menggunakan bahan-bahan sederhana yang murah dan mudah diperoleh oleh masyarakat sehingga masyarakat dapat mengembangkan sesuai dengan kebutuhannya. Komponen-komponen dalam alat tersebut sebagaimana yang ditunjukkan di Tabel 3.

Tabel 3. Daftar Bahan Pembuatan Alat Penyaringan Air Sederhana

\begin{tabular}{|l|l|l|}
\hline No & \multicolumn{1}{|c|}{ Nama Bahan } & Jumlah \\
\hline 1 & Arang & 5 pack \\
\hline 2 & Batu & $300 \mathrm{~g}$ \\
\hline 3 & Kapas & 2 pack \\
\hline 4 & Kerikil & $300 \mathrm{~g}$ \\
\hline 5 & Pasir & $300 \mathrm{~g}$ \\
\hline 6 & $\begin{array}{l}\text { Pipa paralon ukuran } 1 \text { meter }(\mathrm{d} \\
=4 \text { inci) }\end{array}$ & 1 buah \\
\hline 7 & Dop (penutup pipa) d $=4$ inci & 1 buah \\
\hline 8 & $\begin{array}{l}\text { Elbow (sambungan pipa) d }=4 \\
\text { inci, sudut } 45^{\circ}\end{array}$ & 1 buah \\
\hline 9 & Kran (diameter $1 / 2$ inci) & 1 buah \\
\hline 10 & $\begin{array}{l}\text { Drat (sambungan kran) } \\
\text { diameter } 1 / 2 \text { inci }\end{array}$ & 1 buah \\
\hline 11 & Kain saring & 4 buah \\
\hline 12 & Lem pipa & 1 buah \\
\hline 13 & Sil tip & 1 rol \\
\hline 14 & Paku & Secukupnya \\
\hline 15 & Kayu dan papan & Secukupnya \\
\hline 16 & Cat & 1 buah \\
\hline 17 & Kuas & 1 buah \\
\hline
\end{tabular}
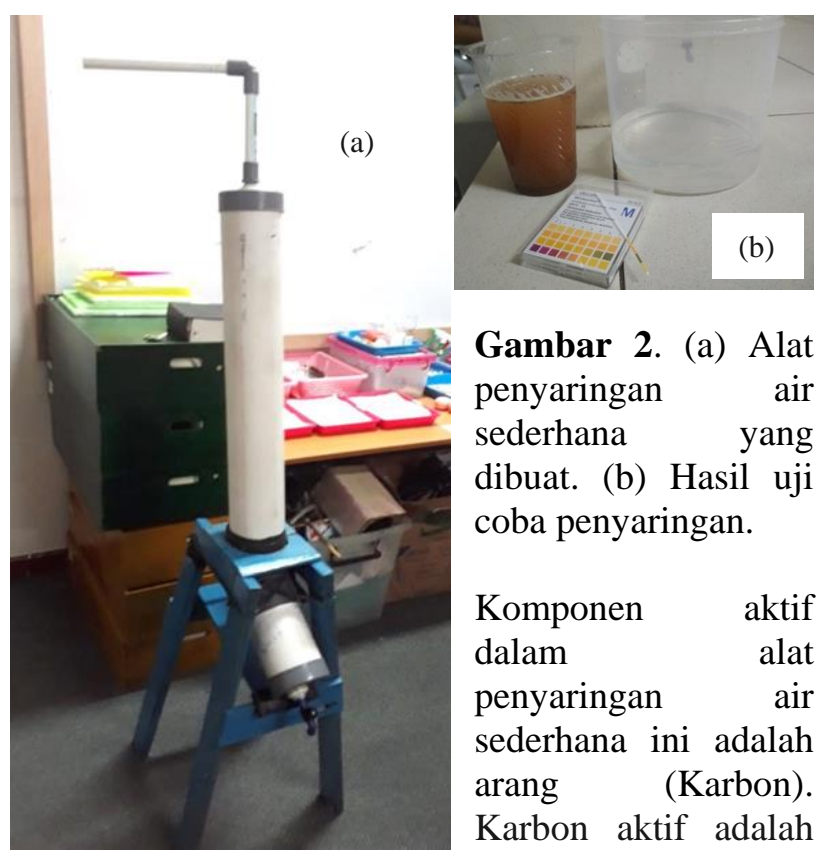

Gambar 2. (a) Alat penyaringan air sederhana yang dibuat. (b) Hasil uji coba penyaringan.

Komponen aktif dalam alat penyaringan air sederhana ini adalah arang (Karbon). Karbon aktif adalah salah satu bahan yang murah dan mudah diperoleh serta efektif untuk menyerap logam berat (Ikhwan,
2010). Alat yang berhasil dibuat (Gambar 2a) diujikan terlebih dahulu dengan menggunakan sampel air kotor dan hasilnya menunjukkan bahwa air kotor berubah menjadi jernih dengan bantuan alat ini. Kadar keasaman air hasil penyaringan juga menunjukkan nilai normal yaitu nilai $\mathrm{pH}$ 6-7 (Gambar 2b).

\section{Hasil Kegiatan Penyuluhan}

Berbasarkan hasil pre-test dan post-test yang dilakukan terhadap warga masyarakat yang mengikuti penyuluhan, kami memperoleh data sebagaimana ditunjukkan oleh Gambar 3.

Soal-soal pre-test adalah soal yang sama yang digunakan untuk post-test. Tujuanya adalah untuk melihat seberapa besar pengaruh kegiatan penyuluhan ini terhadap masyarakat di desa Kedung Dalem. Hasil ini menunjukkan bahwa ada peningkatan pemahaman masyarakat terkait kesadaran air bersih dan pola hidup sehat. Jumlah warga yang menunjukkan peningkatan pemahaman ada sebanyak 4 warga (20\%). Ada satu warga yaitu ibu To*** yang masih belum bisa menjawab dengan benar satu pertanyaan pun sebelum penyuluhan tetapi setelah penyuluhan mampu menjawab semua benar pada post-test. Banyak juga warga yang mampu menjawab semua pertanyaan pre-test dengan benar yaitu 10 warga (50\%). Hal ini menunjukkan beberapa warga juga sudah punya pengetahuan tentang kesadaran air bersih dan hidup sehat.

Secara keseluruhan kegiatan penyuluhan berjalan baik, dan lancer. Peserta penyuluhan meresponsi materi penyuluhan dengan baik, warga cukup antusias mendengarkan dan hal ini terbukti dari adanya pertanyaan-pertanyaan yang diberikan oleh warga pada saat diberikan kesempatan bertanya. Nilai rata-rata pre-test adalah 77,1 tetapi nilai ratarata post-test adalah 82 . Hal ini juga menunjukkan secara umum bahwa pemahaman masyarakat dalam penggunaan air bersih dan hidup sehat juga meningkat melalui kegiatan penyuluhan ini.

Beberapa kendala yang dihadapi dalam penyuluhan ini antara lain:

a. Kehadiran anak-anak yang mengikuti kegiatan penyuluhan ini sedikit banyak mengganggu perhatian ibu-bapak warga yang mengikuti kegiatan penyuluhan. Anak- 
anak masuk dan keluar ruangan serta sering memanggil-manggil ibunya menyebabkan sedikit keributan dalam proses penyuluhan.

b. Beberapa warga masih sulit membaca dan menulis sehingga mahasiswa harus bisa membantu membacakan soal kepada warga yang kesulitan membaca dan membantu menulis tanda $\mathrm{X}$ pada jawaban yang dipilih warga. Alasan kesulitan membaca dan menulis antara lain karena beberapa warga belum melek huruf atau usia warga sudah cukup tua sehingga kurang bisa melihat huruf dan menulis.

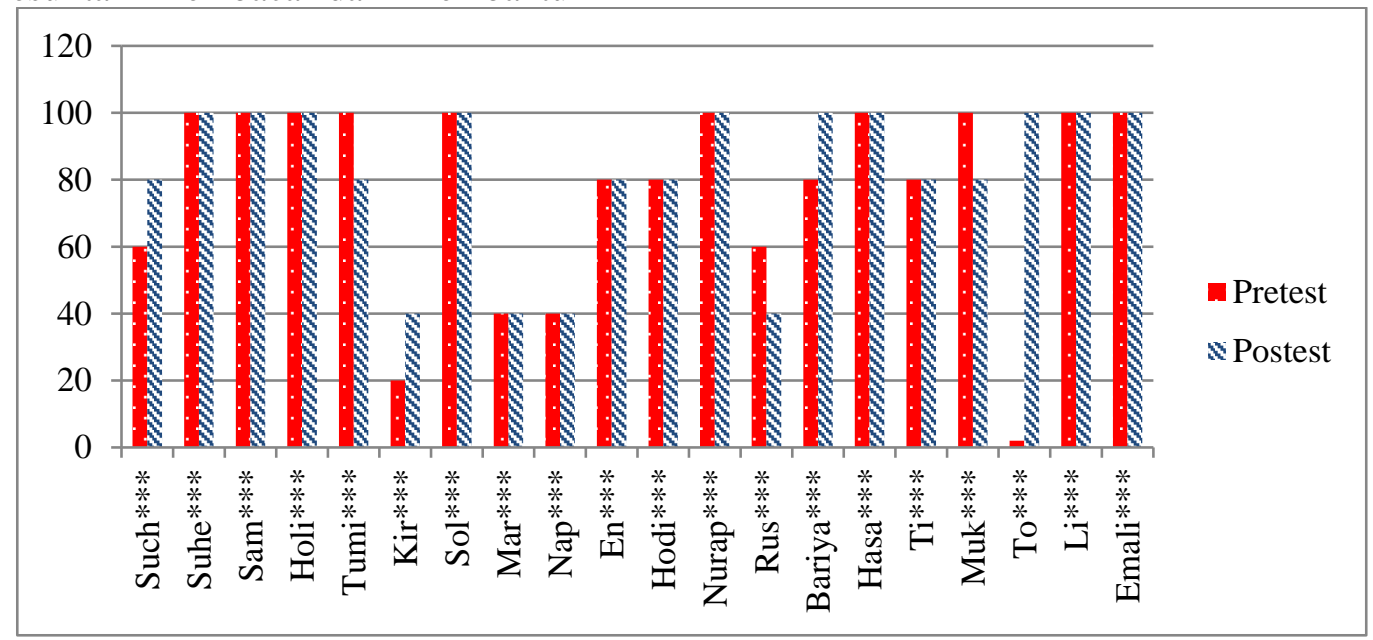

Gambar 3. Hasil Pre-test dan Post-test terhadap masyarakat Desa Kedung Dalem yang mengikuti penyuluhan.

Kendala-kendala yang dihadapi ini diharapkan dapat menjadi masukkan untuk kegiatan PkM berikutnya sehingga kegiatan penyuluhan dapat berjalan lebih baik.

\section{KESIMPULAN}

Kegiatan penyuluhan kesadaran air bersih dan hidup sehat kepada masyarakat di Desa Kedung dalam pada Rabu, 9 Mei 2018 berjalan dengan lancar. Masyarakat terlihat antusias mendengarkan penjelasan dari para dosen Prodi. Pendidikan Kimia dan sesuai dengan hasil tes tertulis secara rata-rata menunjukkan peningkatan pemahaman tentang air bersih dan hidup sehat. Masyarakat juga mendapatkan informasi bagaimana membuat alat penyaringan air sederhana yang dapat digunakan untuk mengatasi masalah sumber air yang kotor di lingkungan sekitar. Berdasarkan hasil eksperimen dan analisis AAS terhadap sampel air di dua lokasi memiliki kandungan logam timbal, kadmium, dan kromium masih pada level yang diijinkan oleh Departemen Kesehatan RI.

\section{UCAPAN TERIMAKASIH (Bila ada)}

Ucapan terimakasih disampaikan kepada LPPP UPH yang telah memberikan bantuan dana dalam pelaksanaan kegiatan Pengabdian kepada Masyarakat dengan nomor PM-016/FIP/I/2018.

\section{REFERENSI}

BPOM. (2010). Mengenal Logam Beracun. Badan Pengawas Obat dan Makanan (BPOM) RI, 2$4 . \quad$ Retrieved from http://biodiversitas.mipa.uns.ac.id/D/D0102/D 010204.pdf

Dharma, W. K., Hoedojo, Nugroho, R. A., Suriptiastuti, Inggrid AT, \& Arif, B. S. (2004). Survei fauna nyamuk di Desa Marga Mulya, Kecamatan Mauk , Tangerang. Jurnal Kedokteran Trisakti, 23(2), 57-62.

Ikhwan, Z. (2010). Sebagai Media Penyaring Penurunan Kadar Besi dan Mangan pada Penjernihan Air Kolam, 150-153.

Profil DinKes Tangerang. (2010). Kabupaten Tangerang Dinas Kesehatan.

MENKES RI.

(2010).

SK_Permenkes_492_2010.pdf.

Lingkungan Hidup dan Kebencanaan 
Susanti, R., Mustikaningtyas, D., \& Sasi, F. A. (2014). Analisis Kadar Logam Berat pada Sungai di Jawa Tengah. Sainteknol: Jurnal Sains Dan Teknologi, 12(1), 35-40. https://doi.org/10.15294/sainteknol.v12i1.542 4 